\title{
Informal learning for citizenship building in shared struggles for rights: Cases of political solidarity between Colombian and Spanish organizations
}

\author{
Sergio Belda-Miquel \\ Alejandra Boni Aristizábal \\ Maria Fernanda Sañudo Pazos
}

Prefinal version of a paper which was published in 2015 in Voluntas.

\author{
Abstract \\ Dominant discourses and practices in international cooperation have been
} characterized by depoliticization and unequal power relationships. However, there also exist a number of more transformative experiences of cooperation, which link Northern and Southern social organizations from a more political perspective on their joint work. These kind of experiences can be considered as learning processes, as in them, and through the construction of confidence and common political positions and strategies, informal and multidimensional learning processes arise, in people and organizations engaged.

Drawing on this perspective, the study approaches five cases of networks that have linked Spanish and Colombian organizations, which promote advocacy and social mobilization for the defense of Human Rights in Colombia. Results show that people engaged in the cases had experienced intense processes of learning which are relevant for the construction of solidarities and an active global citizenship, but also that these processes are full of limitations, tensions and challenges.

\section{Keywords}

Social organizations; international cooperation; politics; informal learning; global citizenship. 


\section{Introduction}

The relation between official development assistance (ODA) and politics is not new. As Carothers y De Gramont (2013) remarked, ODA has always been unavoidably political. Donors have used aid with political purposes and its actions, although supposedly apolitical, have had deep political impacts in recipient countries and territories. Nevertheless, a discourse based on the idea that development and cooperation are purely technical and managerial issues (Ferguson, 1994), has become dominant in the international cooperation system in recent decades. The debate on development and aid has thus become depoliticised, and what has been called managerialism has become the dominant approach (Mowles et al., 2008).

As part of this process of managerialisation, new ideas inspired by the market and private sector rationale have become central in the field of development and international cooperation: efficacy and efficiency, impacts, products and clients of development, etc. (Dart, 2004; Quarles van Ufford and Giri, 2003). Non-Governmental Development Organisations (NGDOs) and other social actors have adopted these ideas, and became project implementors and public service providers. In this process, some of them may have lost the more political profiles they had in the past (Choudry and Shragge, 2011). They also may have become collaborators in a model of cooperation that, far from promoting social transformation, sustains the status quo, reproduces unequal power relationships between Northern and Southern actors (Dar and Cooke, 2008; Mawdsley et al., 2002).

As a number of studies show, the same process has also taken place in Spanish NGDOs (Revilla, 2002; Gómez Gil, 2005). However, it is also possible to find a number of experiences of relationships between Northern and Southern social organisations that are within the international cooperation system, and obtain funds from it, but which work from a more transformative and consciously political perspective of international cooperation. Organisations share common ideas of the changes they pursue, and try to build trusting, long- 
term political alliances for social transformation. International relationships between social organizations with these features have been defined as "political solidarities" (Bringel et al., 2008) -the term that will be mostly used in this paper-, "radical partnerships" (McGee, 2010) or "transformative cooperation" (Fernández et al., 2013).

It can be argued that these kinds of experiences of international cooperation are valuable as long as they are building what could be called a "global radical citizenship", a transnational civil society that articulates transformative political discourses and actions for the expansion of rights (Heater, 2002).

It could also be considered that the construction of this civil society can take place through the learning processes that emerge in people and organisations that work together within the international cooperation system, as new discourses, values, attitudes, knowledge and skills arise through these relationships. The building of political solidarities can thus be considered a process of learning in social action with a powerful emancipatory potential (Foley, 1999). These learning processes are mainly informal, emergent, contextual, and complex (Holst, 2002).

In the paper five case studies of experiences of political solidarity are analysed. These are cases that have linked Spanish and Colombian organisations that have worked together in political actions, such as lobbying, raising public awareness, social mobilisation, etc., in the defence and construction of Human Rights (HR) in Colombia, and that have received the support of funds from the international cooperation system, coming from Spanish public donors.

The aim of the paper is to identify the key features that have modelled the learning processes experienced by the people and organisations engaged in these cases. We will also identify the kinds of learning that these people and organisations profess to have experienced, and the tensions and contradictions that these learning processes in social action face. 
We have adopted an interpretative approach and an essentially qualitative methodological perspective. The results of the study are based on the analysis of 46 semistructured interviews with people involved in the cases, together with the analysis of secondary data.

In the next section, we will approach the key theoretical ideas that have been presented: political solidarity, global radical citizenship and learning in social action. On the basis of these ideas, we explain the analytical framework and the methods used to gather information. Section 6 presents a discussion of the results, structured around the key ideas presented in the framework. Finally, we present some concluding remarks and some preliminary reflections on the theoretical and practical implications of our study.

We consider that our work addresses a gap and may be a contribution in two aspects. In the first place, it tries to explore a certain kind of -more consciously politicised- relationship between social organisations in international cooperation, a kind of relationships which is frequently obscured and has been little explored. In the second place, it tries to valorise and understand these kinds of relationship as informal learning processes in social action. Even though there is a broad literature on learning and capacity building in international cooperation (see, for example, Clarke and Oswald, 2010), there is no specific research on relationships in international cooperation as informal learning processes in social action. This approach on informal learning has been used to analyse various forms of activism (see, for example, Gouin, 2009; Hall, 2009; Choudry, 2009; Ollis, 2011), pointing at certain aspects of processes of individual and collective change that can be very relevant in understanding relationships in international cooperation.

\section{Concepts and assumptions}

International cooperation as political solidarity 
It is possible to set out the characteristics of a different kind of international cooperation, that may be being practised by some individuals, NGDOs and other social organisations in the North, which support processes of radical social change driven by social organisations and movements in the South. Drawing on the contributions of different authors, we can identify some features that this kind of cooperation, which can be called "political solidarity" (Briegel et al., 2008), has:

This practice of international cooperation links organisations that share common political and ethical principles, frameworks and ideas on social change and how to achieve it (Pearce, 2010; Fernández et al., 2013). It brings together actors from very different backgrounds, but which sympathise with similar political ideas (Bringer et al., 2008). Often, it links Northern social organisations with social movements in the South that are articulating political, social and epistemological alternatives to current development models (Fernández et al., 2013).

Another feature of this kind of more specifically political cooperation would be that organisations try to analyse, unveil and confront structural and institutional factors that form the basis of the situations of oppression and impoverishment (Gulrajani, 2010; Fernández et al., 2013). Consequently, these organisations build together political objectives, strategies and actions, which are constantly revised and negotiated (Mowles, 2008; Eyben, 2013). It implies working with flexibility, navigating complexity and adapting to changing political contexts together (Mowles et al., 2008). This kind of relationship is based on trust and political engagement (Eyben, 2006), and it also implies confronting the unequal power relationships that can arise between actors in these alliances.

To approach this kind of alliances implies assuming a certain ontological perspective which has been called "relational" (Eyben, 2008): far from the dominant essentialist perspective in development studies, a relational approach assumes that actors are not 
immutable, but are continually being shaped and transformed by the relationships they maintain (Eyben, 2008).

\section{Global radical citizenship}

These ideas on the meaning and implications of a certain kind of relationship in international cooperation lead us to the idea of global citizenship. Moreover, it could be considered that this kind of relationships can be relevant as long as it involves the construction of citizenship, amongst the people and organisations concerned.

Some authors reject the validity or relevance of the idea of global citizenship, for a big variety of reasons: for example, some consider that the idea can undermine the legitimacy of nation states and the importance of channelling demands at this level (Schattle, 2008); some others argue that participation and deliberation can only genuinely take place at the local and community level (Schattle, 2008), etc. However, it is possible to draw on some other perspectives, which normatively consider global citizenship as the process of building global solidarity (Ellison, 1997), as a transnational political project that aims at the expansion and accomplishment of rights (Heater, 2002), or as the creation of new forms of exercising citizenship at the global level, and the transformation of identities through emancipatory processes (Schattle, 2008).

These elements seem to be directly connected with the political practice of international cooperation described earlier. In order to delve into these connections, the meaning of global citizenship can be refined by drawing on the conceptualisation of "radical citizenship" by Hickey and Mohan (2005). This idea of citizenship tries to go beyond liberal conceptions, which are often exclusively centred on the vision of citizenship as the set of rights and duties recognised by the State. Instead, from a radical perspective, citizenship is seen as a practice: the actions and struggles made by the people in order to expand or defend existing rights, or create new ones (Isin y Wood, 1994:4). At the same time, citizenship is seen as the 
set of attributes (knowledge, values, attitudes, skills, etc.) that people have and develop in order to exert this kind of citizenship (Merrifield, 2002).

This conception of citizenship does not necessarily renounce at the role played by the State as the duty-holder towards citizens' recognised rights, but radical citizenship would be an essentially "bottom-up" process, constructed in organised struggles (Hickey y Mohan, 2005).

In the field of international cooperation, these ideas connect with the one proposed by Bringer et al., (2008) on the "democratisation of development", seen as a political praxis based on solidarity and mutual recognition (Bringel et al., 2008).

\section{Learning in social action}

As has been indicated, relationships in international cooperation can be understood as citizenship building learning processes, as organizations build alliances and act together. We can draw on different contributions coming from the field of adult education, that has recognized the importance of learning in action, as a process of informal learning.

Processes of learning in social action have been described as emergent, informal, nonplanned, tacit and incidental, and which have to be unveiled in order to understand them (Foley, 2004). This learning takes place through relationships, in permanent and dynamic processes, embedded in particular contexts, where social, political, economic, social and cultural factors are at play (Margaret, 2010), as well as power relationships (Pettit, 2010). This learning process can reproduce the status quo and the hegemony of ruling groups, or have an "empowering and emancipatory effect that helps to overcome oppression in society" (Steinklammer, 2012:24).

Social organisations as spaces for citizens and democratic action for social change are key spaces for learning in social action (Foley, 1999; Holst 2002). Through their participation in social movements, individuals and collectives learn new skills and forms of thinking (Holst, 2002:87), and create new forms of knowledge (Choudry, 2009). 
The kinds of learning that emerge in social action can be very diverse: technical (how to perform a certain task), political (how people have power and use it), social, cultural, etc. (Foley, 2004). New knowledge that is acquired in these learning processes can be "expert" or "non-expert" -knowledge that emerge from the practice itself (Kapoor and Choudry, 2010). It also to consider that informal learning takes place through processes that are intellectual, but also experiential and emotional (Pettit, 2010).

\section{Analytical framework}

In this section, and drawing on the work of Gaventa and Tandon (2010) and Foley (1999), a framework is proposed to collect, link and operationalize the ideas indicated above, in order to approach the learning processes in social action of our case studies

On the one hand, following Gaventa and Tandon (2010), three key factors can be identified when approaching collective action processes in the building of citizenship: in the first place, the "micropolitics of mobilisation", a category that includes questions as the strategies, tactics, resources and interactions within the action networks at the different scales (from local to global) that are at play. Secondly, the "micropolitics of intermediation", which refers to the nature of the mediation between the networks, other grassroots and social organisations, and public institutions. These include issues of interlocution, representation, legitimacy, accountability, etc. Thirdly, the "micropolitics of knowledge", a category that encompasses how knowledge is produced and how it shapes the interactions.

On the other hand, Foley (1999) proposes an analytical framework for addressing learning in social action with some similarities to Gaventa and Tandon's approach. For him, approaching these processes implies considering, on the one hand, questions of "macropolitics", changes in political economy and how they connect with changes in forms of 
mobilisation, actions and ideas; on the other hand, questions of "micropolitics", interactions between actors, and how discursive practices are at work in them.

On the basis of these contributions, an original framework can be proposed, with three key categories, inspired in Gaventa and Tandon (2010), which are connected between them, and feature the central category of "learning for global radical citizenship" (see figure 1).

In the sphere of "mobilisation" we consider the subcategories of "objectives, strategies and actions" and "interactions within the structures", which entails questions such as the nature, mechanisms and spaces of relationships within the networks. In the category of "intermediation", a differentiation can be proposed between "interactions with public institutions", and "interactions with grassroots organisation". The category of "knowledge" involves questions linked to the production of discourses, knowledge, values or ideology.

The category of "learning for global radical citizenship" encompass all the different kinds of learnings that emerge in peoples and organisations in social actions, from the ethical to the political, individual to collective, from skills and values to attitudes, etc. The links and interactions between the different categories are complex and multidimensional, and they all take place in a particular context, so political economy issues have to be considered.

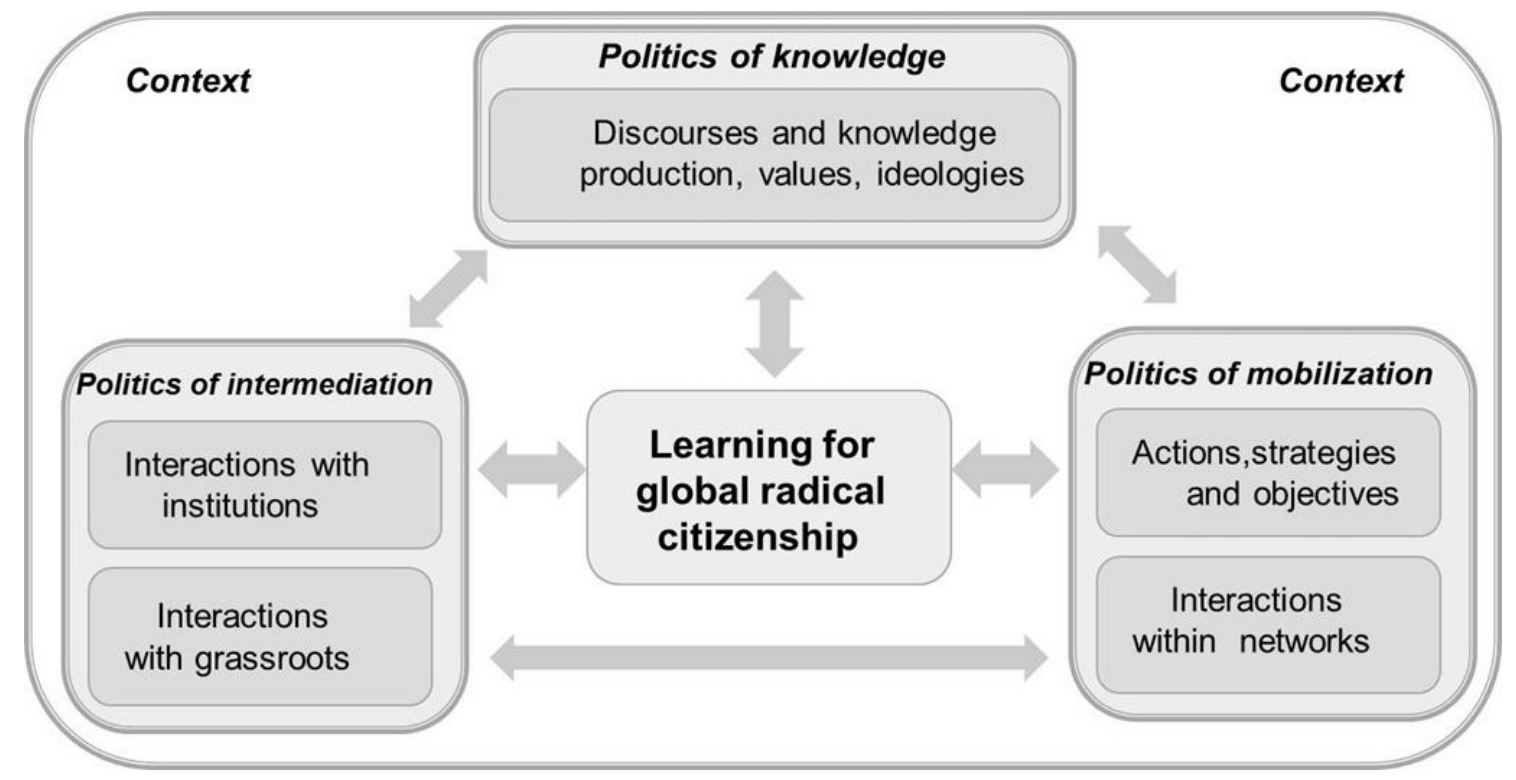


Figure 1. Learning processes for global citizenship building in the social action of networks. Source: Self-elaboration, based on Gaventa and Tandon (2010) and Foley (1999).

\section{Case studies}

As mentioned, the study approaches five case studies of experiences of international cooperation that have linked different Spanish and Colombian social organisations (NGDOs, local NGOs, unions, HR organisations, grassroots organisations, etc) in the joint political work in the defence and expansion of rights in Colombia. We made a purposive selection of case studies, considering that we wanted to address cases that could be considered of "political solidarity".

The cases have some common features: 1) The five networks carry out various political actions: lobbying Spanish institutions and making public denouncements, preparing reports on the HR situation in Colombia, organizing demonstrations, raising public awareness, supporting Colombian organizations to find new allies in Europe and access international HR forums, etc. 2) Relationships between Spanish and Colombian organisations in the cases have been in existence for at least four years, and still continue. 3) Processes carried by these networks have been supported by funds coming from various Spanish public donors.

The five case studies are briefly described below:

Asturian Protection Programme for Victims of Human Rights Violations in Colombia (Programa Asturiano de Protección de Víctimas de Violaciones de los Derechos Humanos en Colombia). This is formally an institutional programme of the Regional Government of Asturias, but it was proposed and is coordinated and implemented by the NGDO Soldepaz - Pachakutik, with the support of a committee of nine Asturian organisations (composed of NGDOs, trade unions and HR organisations, amongst others). It works with a Selection Committee in Colombia, initially formed by the Central Union of Workers of Colombia (Central Unitaria de Trabajadores de Colombia, CUT), which has been joined by four Colombian HR organisations. The Programme shelters human rights defenders at risk, in 
Asturias, for a period of six months. The people given refuge are chosen by the Selection Committee. During their stay in Asturias, they carry out a number of awareness-raising and advocacy actions (at local, regional, national and European levels) on HR violations in Colombia, create new contacts between their home organisation and Spanish organisations, and provide and receive training. Additionally, a Verification Committee created by the Programme, composed of members of social organisations and Spanish policy-makers and public workers, visits different regions and communities in Colombia annually to perform a verification of HR. Following this, a report is drawn up, which provides the basis for advocacy actions. The Programme continually carries out actions to denounce HR violations and promote advocacy. It was formed in 2001.

Basque Protection Programme for Defenders of Human Rights (Programa Vasco de Protección a Defensores y Defensoras de DDHH, PV). Similar to the previous case, the Basque Programme was created under the auspices of the Basque Government, and coordinated by the 'Kolektiba Colombia' (which encompasses five NGOs and NGDOs from the Basque Country). Unlike the Asturian Programme, the Basque Programme Selection Committee is composed of members from Spanish institutions (Basque Government departments, universities, and Basque peace and HR organisations). The type of actions performed, including the verification visit, are very similar to those of the Asturian Programme. It was formed in 2011.

Committee for Human Rights of Women and Peace in Colombia (Mesa por los Derechos Humanos de las Mujeres y la Paz en Colombia). This network is coordinated by the NGDO Atelier. Over the years it has incorporated between 8 and 15 Spanish organisations (trade unions, NGDOs, university institutes, feminist organisations) and 5 to 9 Colombian organisations (NGDOs and grassroots women's organisations) -the number varied depending on the period-. They carry out awareness-raising and advocacy actions on the issue of the HR 
of women in Colombia. Of particular note are the lobbying actions made towards regional and national parliaments to take a stance on the issue, the production and distribution of documentaries, conducting international meetings, positioning the issue in the mass media, etc. It was formed in 2007 and has received funding from Spanish national aid agency and the Valencian aid agency.

Support for the Minga of Social and Community Resistance (Apoyo a la Minga de Resistencia Social y Comunitaria). This is the process by which the Coordination for the Rights of Indigenous Peoples (Coordinación por los Derechos de los Pueblos Indígenas' CODPI, which brings together 5 Spanish NGDOs and NGOs) and the Centre for the Autonomy and Rights of Indigenous Peoples (Observatorio por la Autonomía y los Derechos de los Pueblos Indigenas, ADPI) have sustained the intense social mobilisation process of the Minga. The Minga began in 2004 as a process of the main indigenous organisations in Colombia converging amongst them and with other grassroots organizations to defend their rights, through marches and other forms of political pressure towards the Colombian state. ADPI and COPDI have been supporting this process since 2010, bringing international attention to the actions of the Minga movement, mainly through social media, making demands on the Spanish State for the rights of indigenous peoples of Colombia (following presumed violations of HR by Spanish companies), helping indigenous leaders to build alliances in Spain, or increasing their presence in international HR forums.

Support by the NGDO Initiatives for International Cooperation for Development' (Iniciativas para la Cooperación Internacional al Desarrollo, ICID) for the local NGO Open Workshop (Taller Abierto, TA). ICID has carried out projects with TA for improving the organisational processes of Cauca women displaced by war. Furthermore, these organisations have conducted advocacy actions directed at the Spanish aid agency and the 
Spanish Foreign Ministry, to demand a response to threats made towards women's organisations. The relationship began in 2005.

\section{Methods used}

For this study, a total of 46 semi-structured interviews were carried out ${ }^{1}$ (37 individual and 9 group interviews) between January and July 2013, with people which have participated in the case studies. Between 6 and 15 interviews were conducted for each case analysed. Balance between the number of interviews with people belonging to Spanish organisations and to Colombian organisations was sought (29 and 17, respectively). Furthermore, people with different levels of responsibility in the cases was interviewed, ranging from people with a central coordinating role to people who have only participated sporadically.

The primary information obtained was supplemented by secondary information, essentially documents produced by the organisations themselves: websites, reports, booklets, leaflets and audiovisual material developed for disseminating experiences; project formulation documents; internal and external evaluations of projects; public statements, manifestos, denouncements, letters addressed to institutions, etc.

From an interpretivist perspective, we tried to capture the meanings and interpretations that people gave to the experience (Corbetta, 2003), specifically, how they experienced the learning process, and what the drivers and the results may have been. For information processing, a qualitative content analysis was performed on the interviews and secondary documentation, based on predefined categories in the analytical framework. In this analysis, these categories were refined and new subcategories obtained. From these categories and subcategories, discussion was organised around the common themes and

\footnotetext{
${ }^{1}$ The contents of the interviews concerned the issues identified in the theoretical and conceptual framework: interviewees were asked about their and the organisation's role in the case study, about the context, on the relationships with the other actors and institutions involved, and on the personal and organisational learning that was perceived to have been acquired.
} 
trends, differences and tensions that were identified. Triangulation of the information, both within and between methods (Mikkelsen, 2005) was sought.

\section{Analysis and discussion}

\subsection{Which features of the political solidarity processes under study modelled} learning processes?

In this section, we identify the characteristics of the processes under study that seemed to be relevant for understanding how learning processes were modelled.

\section{Objectives and strategies:}

In all the cases, there is a particular central objective that serves as an "entry point" or reference point: the temporary sheltering in Spain of threatened Colombian activists, defense of the HR of women, or support for a specific social mobilisation process in Colombia. Around this specific objective, a whole series of political actions are developed (lobbying, awareness raising, denunciation, networking, etc.). This generates far-reaching and complex processes with a strong political content around a specific issue, which become a driver of learning.

Furthermore, all the cases feature an implicit common objective: the creation of widespread solidarity movements with Colombia in Spain. Therefore, almost all these experiences try to bring together a large number of organisations of varying profiles. In some cases it also concerns organisations that do not normally work together, or even mistrust each other, but that find a common issue to work together on the topic of HR situation in Colombia. Although this diversity may eventually lead to tensions, it also appears to be a strong driver of learning through the exchange. An attempt is made to build permanent alliances, not dependent on a specific project, so that they can become open, long-term learning processes.

It may also be noted that, together with long-term objectives, the experiences try to respond to urgent particular situations (e.g. in response to a specific murder). In this way, they 
seek to combine long-term processes with urgent action, which may create difficulties, but also facilitates learning by placing operational, short-term issues in conjunction with broader political discussions, considerations and objectives.

\section{Relationships between organisations:}

Almost all respondents, and numerous documents on the cases, emphasise the attempts made to establish equal relationships between the organisations. To do so, they try to generate models and protocols for communication, information and decision making to facilitate horizontal relationships, e.g. conducting periodic face-to-face meetings to debate and make decisions; permanent online communication open to all organizations to share information and create discussion; decision-making mechanisms by consensus, etc.

In all cases, there is a Spanish person or organisation that plays the role of "coordinator". They are also accountable to the public donors of the funds they get through projects. They centralise much of the more bureaucratic work, freeing up other organisations in the network so they can focus on political action. Depending on the case, the level of commitment from the other organisations in the networks is highly variable. Generally speaking, there are a limited number of organisations with continuous participation in the actions, and a greater number of organisations with reduced participation.

Alongside the formal spaces and relationship channels (both face-to-face and online), many of the interviewees highlighted the importance of informal meetings, casual conversation, coexistence and everyday social contact between members of organisations (e.g. when being given refuge in Spain, or in Spanish trips to Colombia), as central elements in building relationships and confidence, identifying these as powerful drivers of learning.

Regarding this issue, we can also highlight the central importance of building close personal friendships. In some cases, these personal relationships have made it easier for organisations to begin working together, and for the processes to have continuity. They play a 
particularly important role in times of crisis and conflict within the networks, facilitate ongoing dialogue and communication, and appear to be fundamental when operating in sensitive, complex and shifting political contexts, as is the case in Colombia, which require relationships of great trust.

Knowledge, discourse and ideology

Political affinity is indicated in all cases as a key driver in building relationships. It generates mutual understanding and trust, common registers, facilitates open political debate, etc. In our cases, this affinity involves having or building common views on key issues such as: the causes of the conflict in Colombia, where all cases consider that the Colombian conflict is based on problems of a social, political, and economic nature, deriving from the advance of neo-liberalism; ideas for alternatives, placing popular movements (syndicalist, peasants, women, indigenous peoples, students, etc.) as key actors in the construction of alternative development models and promoting peace; views on the direct responsibility of the Colombian State, other states (such as the Spanish) and other actors (mainly transnational companies) in the conflict in Colombia; the role of international cooperation, which should support popular movements. All cases share the belief in connecting the struggles and building solidarity between grassroots movements in Colombia and Spain, in opposition to the neoliberal model and its consequences.

Mediation with institutions.

Given the nature of the actions carried out during the experiences, a number of opportunities for interaction with the Spanish public institutions are generated, both with State and regional development cooperation agencies, and with various institutions that may have some relevancy in regard to HR compliance in Colombia. In the experiences, meetings are made with political representatives, political parties, civil servants, etc., at various levels of government. Although responsibility for creating dialogue frequently falls to Spanish 
organisations, it is attempted, whenever possible, that the members of the Colombian organisations interact directly with the Spanish institutions. In all cases, they try to seek out specific public servants within the institutions, who are more responsive to the demands, with whom they can foster a relationship of trust and mutual understanding.

Interviewees considered the general attitude of the institutions towards the organisations and their claims to vary from receptivity to distrust or disinterest. Institutions frequently seem to show interest in the purely "humanitarian" dimension of the cases (such as the protection of life), and less interest or suspicion towards more overtly political claims, or to denunciations against other actors, such as companies and governments. Thus, organisations are often forced to navigate between the depoliticised, bureaucratic discourse and requirements of the institutions, whilst trying to promote a more critical, political discourse and action. It is a complex situation, but one that can also promote learning.

\section{Mediation with grassroots organisations.}

In all the cases analysed, there was a significant presence of Colombian grassroots organisations: either directly present in the networks, or through the presence of local Colombian NGOs closely linked to grassroots organisations. In general, the perspective displayed by respondents, and collected in some documents, is that their actions prioritise gathering the demands, views and claims of grassroots organisations that are, in fact, considered as the source of legitimacy of their actions. Contact with grassroots organisations could be considered a powerful driving force behind learning, by connecting the networks with the processes of resistance and alternatives arising from the "bottom-up".

However, it could be said that grassroots organisations do not play a leading role in several of the cases analyzed, whose leaderships are often assumed by NGDOs and NGOs. Furthermore, Colombian grassroots organisations, more focused on local work than on 
international networks, often have trouble following the work patterns in the networks we have analysed, which limits their active participation.

On the other hand the presence of Spanish grassroots organisations is much more limited in the cases. Moreover, in those cases where these types of organisations were involved, they usually concern more structured and professionalised organisations (such as trade unions). There is much less contact with informal movements (as the 15-M or 'indignants' movement, which was frequently mentioned and is very respected among the persons interviewed), a fact that is seen as a major limitation by several interviewees.

\subsection{Which learning emerged and in whom?}

In the analysis, we have identified that different kinds of learning emerged in the people and organisations involved in the cases. Amongst these we can highlight the following:

Learning for political analysis: members of the Spanish organisations, especially those who have held more responsibility in the cases under study, state that they have had a valuable learning experience, in terms of their capacity to make a general analysis of the Colombian political context, of the causes and effects of the Colombian conflict, and the changing political situation in the country. They also value the knowledge of the reality and actions of the Colombian organisations in their struggles. For their part, members of the Colombian organisations state that, most of all, they have learnt about the solidarity movement in Spain, the NGDO sector and the workings of the international cooperation system (essentially, how to operate within it and achieve funding). Those Colombians most involved in advocacy actions also learnt about the institutions of the Spanish State in relation to HR and, to a lesser extent, about Spanish local organisations and social movements and their struggles to demand rights. 
Learning about new development models: through exchanges between members of organisations, particularly during their stays in Spain and Colombia, relevant reflections on development models occur in both Colombian and Spanish individuals. Several Colombians point at paradoxes of the Spanish socio-political reality, defined by them as a model which allows free expression but finds other forms of repression, or ensures public services, but has a consumerist and commodified society as its base. For its part, members of Spanish organisations seem to have become familiar with the contents, meaning and practice of alternative development models arising in movements in Latin America, such as that of 'Buen Vivir', or the notion of the 'right to territory' from an indigenous perspective.

Learning about working approaches: in the case studies, the organisations often employ certain concepts and common approaches in the field of international cooperation, often strategically, as this terminology is required by funders: gender-based approach, human rights-based approach, sustainable development, etc. Although these are usually concepts that have been constructed within the international cooperation system, in the cases under study it is possible to observe interesting learning processes to adapt, define and give new meaning to these concepts in particular contexts, based on the worldviews and political positions of the local organisations. For example, the idea of sustainable development is, in some cases, resignified from an "anti-productivist" perspective.

Instrumental learning: Members of the organisations also emphasise the acquisition of instrumental skills. In the case of the Spanish organisations, these are mostly concerned, firstly, with advocacy skills (identify and interact with key people within institutions, produce messages with impact in the mass media, etc.); secondly, with project management, learning to combine the rigid bureaucratic requirements of funders with the complex and changing realities and demands of the Colombian organizations with which they work. For the Colombian organisations, several interviewees also emphasised learning about advocacy and 
learning to apply for, plan and manage projects funded by Spanish institutions. Both Spanish and Colombian organisations also emphasised learning to work in a coordinated and reasonably democratic way in networks that bring together groups of very different organisational and ideological profiles.

Ethical learning: most members of the organisations emphasised learning to work together, through behaviour based on values such as respect for autonomy, flexibility, tolerance, openness to dialogue, working by consensus and accepting dissent, etc.

Learning about symbolism and representations: another critical issue identified is the transformation that occurs in individuals and groups in relation to the representation of the other'. On the one hand, it seems that Spanish organisations have progressed in terms of considering Colombian activists and organisations, not as mere 'victims' of a conflict, but as key political actors in the transformation of Colombia -and in global transformation. However, it is worth mentioning that, for some of the Colombians interviewed, the view of the Colombians as victims perseveres in some Spanish organisations or, conversely, there is a certain "romanticisation" of the activism of Colombian organisations. On the other hand, Colombians have deepened in their views of the Spanish organisations as political allies, compared to the previous viewpoints of some organisations, which would have considered them as mere 'donors'.

Learning on the private-personal sphere: participation in the case studies is experienced as transformative for a large number of the people involved, also on issues that relate to the areas of personal attitudes and choices. Several people mentioned that, through participation, they have confronted attitudes as consumerism and sexism, have learned to better manage emotions such as fear, anger or frustration, have deepened in their personal commitment as activists, have improved in their ability to adapt to different contexts, have improved their self-esteem, etc. These types of learning processes have mainly occurred in 
people who have had more space to share and create close relationships with people from the other country, or when they have visited the country of their allies more often or for longer periods of time.

\subsection{Challenges, tensions and contradictions in the learning processes.}

In the case studies, we have identified some of the key issues in building political solidarities, as well as the learning that emerges. However, these processes are not without difficulties, tensions and contradictions, amongst which we can identify the following:

Firstly, we could mention the problem of the possible concentration of learning. As we have seen, the processes analysed are complex: there are a large number of actors involved, the information exchanged is abundant, the contexts in which they operate are very complex and shifting, etc. This causes a very high number of diverse and interconnected learnings to emerge, but which are concentrated in a very limited number of already highly trained people who are at the centre of these processes. The cases face the tension of trying to be effective and efficient, whilst promoting participation. The challenge is to promote, on the one hand, greater participation within each organisation, as usually only one or just a few people from each organisation participate effectively in the work; and, on the other hand, the participation between organisations, because often much of the work falls to NGDOs or other professionalised organisations in the networks, rather than grassroots organisations, who often delegate responsibilities, which produces less intense learning in its members.

A second issue, related to the previous one, has to do with the tension between learning on the individual level and learning on the collective/institutional level. Although some of the learning mentioned above occurs at the level of the whole organisation, much learning seems to occur on a purely individual level. It becomes a challenge, therefore, to make learning produce changes in the organizational culture, not just in individuals, in a way 
that the retention of learning is not solely dependent on certain people remaining within the organisations.

A similar situation occurs in the public institutions with which the organisations in the case studies interact. We have seen that a political strategy of the organisations and networks is to seek and create collaboration with key people within the institutions. However, although specific individuals learn and change through these interactions, there is a risk that the relationships with these institutions end up depending on specific individuals, and learning and changes are not actually produced in the institutions themselves.

A third tension worth mentioning concerns the role of personal friendships in learning. We have seen that friendship, endearment and personal trust play a fundamental role as a means of promoting learning of a political nature. Nevertheless, tension arises between strengthening relationships between specific individuals as a means of strengthening networks and relationships amongst organisations, and the risk of making these relationships between organisations dependent on purely personal friendships and affinities.

In fourth place, it is possible identify a tension related to political positions. It concerns the difficult balance between adopting a unifying and "low political profile" discourse and more critical positions. In the cases studied, the organisations sometimes choose to look for discourses which can bring together a great number of organisations of very different profiles, and are acceptable to the institutions and the public. However, the discourse created can be too shallow and ambiguous, not very critical and easily exposed to cooptation. In this way, it is possible to miss a learning opportunity through more critical debates. Conversely, more critical and 'politically incorrect' discourses (for example, openly anti-capitalist positions, or those which explicitly hold certain public actors or companies accountable for human rights violations), can facilitate critical learning, but may not be acceptable for certain organisations, 
preventing the possibility of generating broader alliances, or garnering the support of institutions or the public.

A fifth question concerns the imbalance in learning between organisations from the North and the South. In the cases, we have identified that important lessons are produced in both Spanish and Colombian people and organisations. However, there are differences in learning between them. For example, in the Spanish, more learning is produced about the general political context in Colombia, or about Colombian social movements, whilst the Colombians' learning is generally more limited to knowledge of international cooperation system and how to "use" it. The Spanish learn more about the paradigms and the alternative approaches emerging from the South, whilst Colombians acquire less knowledge about alternative paradigms and grassroots resistance in the Spanish context. This could be a potentially contradictory situation in a type of relationships that, according to the respondents themselves, aspires to be "bi-directional", horizontal, and in which alternatives and struggles are shared.

Another tension derived from another kind of imbalance in learning is that which occurs between professionalised organisations and grassroots organisations. It has already been noted that more learning takes place in professionalised organisations than in grassroots organisations in the networks analysed. This is particularly true in the case of Spanish organisations, as learning takes place almost exclusively in NGDOs, with little learning produced in Spanish grassroots organisations, which are absent or play a secondary role in almost all cases.

A final key issue deals with an even broader debate: the role of public funding in these processes. It seems clear that much of the richness and diversity of the learning that emerges in people and organisations would not have been possible without the existence of public funds provided by the international cooperation system. It seems that the organisations in our 
cases have not received political pressures from donors, apart from the difficulties and rigid bureaucracy involved in managing funds. However, something they are exposed to is the variability and unpredictability in accessing public funds and, in recent years, the large reduction in these funds. The challenge is to propose a model of cooperation and relations that do not necessarily renounce public financing, but seek to use it as a driver for the formation of citizenship through learning, without these processes and relationships depending, ultimately, on the existence of this funding.

\section{Concluding remarks}

In terms of findings, some features of a more political and transformative approach to cooperation have been identified in the study. These features challenge current approaches to international cooperation and call for a more political and horizontal, "bottom-up" and citizenship building- oriented cooperation. As it was shown, some of these features seem to be powerful drivers for informal learning: e.g., the construction of broad, inclusive and long term political alliances; the construction of political and critical common positions, linked to grassroots ones; the relevance of the affective and emotional issues in the relationships, etc.

We found how these drivers may have facilitated the emergence of different learnings in individuals and organisations engaged in the case studies, from ethical to political learning, from the individual to the collective, from skills to values, etc. However, the learning processes we encountered face a number of tensions and contradictions: a great number of different learnings can emerge, but they can be concentrated in a few people and organisations, they can take place exclusively at the individual level, or be unequal between individuals and organisations from the North and the South.

The findings direct to a number of new issues on which to focus further work, relevant to organisations seeking to build transnational political solidarity. For example: how to address 
the challenges presented to organisations in order that their relations produce more profound learning in a greater number of individuals and groups? Probably organisations must delve into issues of participation within and between organisations, deep into their links with grassroots organisations, and continue to transform the, usually hidden, unequal power relations in their own networks.

Regarding the implications of this work for other actors, other questions emerge: Can the cases analysed serve as an inspiration for other cases of cooperation -for example, those which operate in a less politicised context and with a less mature civil society than that of Colombia, or Latin America in general?. If public donors - not only from the North, but also from the South- could recognise the value of this kind of more overtly political cooperation and its relevance as a learning process for citizenship building, which specific policies should be articulated in order to promote it?

Finally, we believe that the article has identified the need to further explore some theoretical issues. We believe that the proposed theoretical perspective has allowed us to appreciate the emancipatory potential of informal learning processes in certain relations of international cooperation, but we understand that it fails to capture the full complexity of these learning dynamics. For example, the dynamics between individual and collective learning processes, or the interaction between intellectual, experiential, and emotional-affective forms of learning. These are issues about which a rich theoretical development exists, which could be connected to the issues explored in this work in further research. 
References

Bringel, B., Landaluze, J., and Barrera, M. (2008). Solidaridades para el desarrollo: la política de "cooperación activista" con el MST brasileño. Revista española de desarrollo y cooperación, 22, 195-209.

Carothers, T., and De Gramont, D. (2013). Development aid confronts politics: The almost revolution, Carnegie Endowment for International Peace, Washington.

Choudry, A. (2009). Learning in social action: Knowledge production in social movements. McGill Journal of Education/Revue des sciences de l'éducation de McGill, 44, 5-18.

Choudry, A., and Shragge, E. (2011). Disciplining dissent: NGOs and community organizations. Globalizations, 8, 503-517.

Clarke P, and Oswald, K. (2010). Why reflect collectively on capacities for change?. IDS Bulletin 41, 1-12.

Corbetta, P. (2003). Metodología y técnicas de investigación social, McGraw-Hill, Madrid.

Dar, S., and Cooke, B. (2008). The new development management: critiquing the dual modernization, Zed Books, London

Dart, R. (2004). Being "business-like" in a nonprofit organization: A grounded and inductive typology. Nonprofit and Voluntary Sector Quarterly, 33, 290-310.

Ellison, N. (1997). Towards a New Social Politics: Citizenship and Reflexivity in Late Modernity. Sociology, 31, 697-717.

Eyben, R., (2006). Relationships for aid, Routledge, London

Eyben, R. (2008). Power, mutual accountability and responsibility in the practice of international aid: A relational approach, Working paper 305, Institute of Development Studies, Brighton.

Eyben, R. (2013). Uncovering the politics of "evidence" and "results". A framing for 
development practitioners, Institute of Development Studies, Brighton. Electronic resource, available at http://www. ids. ac. uk/ [accessed 20 November 2013].

Ferguson, J. (1994). The anti-politics machine: "development," depoliticization, and bureaucratic power in Lesotho, University of Minesotta Press, Minesotta.

Fernández, G., Piris, S., and Ramiro, P. (2013). Cooperación internacional y Movimientos sociales emancipadores: bases para un encuentro necesario, Universidad del País Vasco-Euskal Herriko Unibertsitatea, Bilbao

Foley, G. (1999). Learning in Social Action: A Contribution to Understanding Informal Education, Zed Books, London.

Foley, G. (2001). Radical adult education and learning. International Journal of Lifelong Education, 20, 71-88.

Foley, G. (2004). Dimensions of adult learning: Adult education and training in a global era, Open University Press, Maidenhead, Berkshire.

Gaventa, J., and Tandon, R. (2010). Globalising citizens: New dynamics of inclusion and exclusion, Zed Books, London.

Giri, A.K., and van Ufford, P.Q. (2003). A moral critique of development: in search of global responsibilities, Routledge, London.

Gouin, R. (2009). An antiracist feminist analysis for the study of learning in social struggle. Adult Education Quarterly, 59, 158-175.

Gómez Gil, C.. (2005). Las ONG en España: de la apariencia a la realidad, Los libros de la Catarata, Madrid.

Gulrajani, N. (2010). New vistas for development management: examining radicalreformist possibilities and potential. Public administration and development, 30, 136-148.

Hall, B. (2009). A river of life: Learning and environmental social movements. Interface: a journal for and about social movements, 1, 46-78. 
Heater, D. (2004). World citizenship: cosmopolitan thinking and its opponents,

Continuum studies in citizenship, Continuum, New York and London.

Hickey, S., and Mohan, G. (2005). Relocating participation within a radical politics of development,. Development and change 36, 237-262.

Holst, J.D. (2002). Social movements, civil society and radical adult education. Praeger Pub Text, Westport, CT

Houtart, F. (2001). Hacia una sociedad civil globalizada: la de abajo o la de arriba, conference at the Foro Mundial de las Alternativas, Davos, available at biblioteca.clacso.org.ar/ar/libros/osal/huttar.doc [accessed 28 november 2013]

Isin, E.F., and Wood, P.K. (1999). Citizenship and identity, Sage, London

Kapoor, D., and Choudry, A. (2010). Learning from the Ground Up: Global Perspectives on Social Movements and Knowledge Production, Palgrave Macmillan, London and New York Maier, F., and Meyer, M. (2011). Managerialism and beyond: Discourses of civil society organization and their governance implications. VOLUNTAS: International Journal of Voluntary and Nonprofit Organizations 22, 731-756.

Margaret, J. (2010). Capacity development processes within a social movement: Päkehä Treaty Workers' Movement. IDS Bulletin 41, 68-78.

Mawdsley, E., Townsend, J., Porter, G., and Oakley, P. (2002). Knowledge, power and development agendas: NGOs North and South, Intrac, Oxford.

McCourt, W. (2008). Public management in developing countries: from downsizing to governance. Public Management Review 10, 467-479.

McGee, R., (2010). An international NGO representative in Colombia: reflections from practice. Development in Practice, 20, 636-648.

Merrifield, J. (2002). Learning Citizenship. IDS Working Paper 158, Institute of Development Studies, Brighton. 
Mowles, C., Stacey, R., and Griffin, D. (2008). What contribution can insights from the complexity sciences make to the theory and practice of development management?. Journal of International Development, 20, 804-820.

Ollis, T. (2011). Learning in social action: The informal and social learning dimensions of circumstantial and lifelong activists. Australian Journal of Adult Learning, 51, 248-268

Pearce, J. (2010). Is social change fundable? NGOs and theories and practices of social change, Development in Practice, 20, 621-635.

Pettit, J. (2010). Multiple faces of power and learning. IDS Bulletin, 41, 25-35.

Revilla, M. (ed.) (2002). Las ONG y la política, Istmo, Madrid

Schattle, H. (2008). The practices of global citizenship. Rowman \& Littlefield, Plymouth

Steinklammer, E. (2012). Learning to Resist: Hegemonic Practice, Informal Learning and Social Movements. In Hall, B.D., Clover, D.E., Crowther, J., and Scandrett, E., Learnning and Educationfor a Bettter World, Springer, Rotterdam. 